\title{
Treatment of Grey Water using Natural Zeolites
}

\author{
A. Sangeetha, M. Jamuna , N. Manoj
}

\begin{abstract}
Water is the inevitable source for all living things. Due to rapid development in industrialization and urbanization leads to contamination of surface water as well as groundwater which results in water scarcity. Thus grey water which is easily available can be considered as an alternate source of water. Grey water is the waste water generated from office buildings or household appliances like bathrooms, kitchens, washing machines, etc. without fecal contamination. The usage of the soap solution in bathrooms, kitchen dish washing areas and detergents used in washing areas leads to the increasing carbonates and bicarbonates of calcium and magnesium ions in grey water. The present study deals with the treatment of grey water by boiling and zeolite process for the removal of hardness. Natural zeolites are environmentally and economically acceptable hydrated alumina-silicate materials for grey water and wastewater treatment. The treated water can be used for laundry purposes, toilet flushing and gardening thereby reducing the demand for fresh water.
\end{abstract}

Keywords - Calcium ion, Grey water, Magnesium ion and Natural Zeolite

\section{INTRODUCTION}

Natural zeolites play a predominant role in the grey water treatment. It removes the metal ions that present in the grey water. Grey water is term used for the waste water from the households, industries. It mainly includes the waste water from bathrooms, laundries and kitchen. Though waste water contains dissolved and suspended organic and inorganic matter and odors, chemical contaminants is more dangerous. The presence of surfactants in the laundry and bathroom waste water plays a major role in causing hardness. Hardness is defined as the presence of carbonates and sulphate in the form of calcium and magnesium. It is a risk factor that affects the usage of recycled waste water. The recycled water which is used in the laundries can result in poor performance of foaming action in soap and detergent. Due to the high amount of dissolved minerals it cannot be used in irrigation. It also causes various skin diseases such as eczema which makes our skin dry. And to this water cannot be used in industrial equipment's such as cooling tower, containers and pipes, due to the formation of scalp on the surfaces and it will cause corrosion. Due to the ability of ion exchange process and adsorption, the natural zeolites producing the expected results in the hardness treatment of grey water.

Zeolites are the crystalline micro porous aluminosilicates, which allow absorbing water and other cation. Natural zeolite has a high capacity of cationic

Revised Manuscript Received on October 18, 2019.

Jamuna.M, Assistant Professor, Department of Civil Engineering, Kumaraguru College of Technology, Coimbatore.

Manoj.N, Pursuing Masters, Environmental Engineering at Kumaraguru College of Technology, Coimbatore.

Sangeetha.A, Pursuing Masters, Environmental Engineering at Kumaraguru College of Technology, Coimbatore. exchange through which the metal ions can be removed. It can be able to retain the particles up to 5 microns. Zeolites is of granular and powder form, here powder form zeolite is used. This paper discusses the removal of hardness using natural zeolites. And it achieves the expected results in the removal of hardness.

\section{MATERIALS USED}

\section{A. Grey Water}

The water from laundries and bathrooms of households is referred as grey water. It contains metal ions due the presence of surfactants which results in the usage of detergents and soaps. The presence of metal ions such as calcium and magnesium of carbonates and sulphate cause hardness of water. Grey water is has the crucial problem in discharging and treatment measures. If it is discharged to the ground or lake or the open bare land it causes various problem. It results in ground water contamination and spoiling the lands which affects in vegetation. The grey water is to be treated properly by removing all the organic and inorganic matter, odor and chemical contaminants too. The grey water to be treated is collected from our institution.

\section{B. Sand}

Sand is the excellent filtering medium which is used from ancient days. A good example is the self-purification of streaming river over the layers of sand and gravel. It traps the suspended and dissolved mater within the intercities of the pores present in it. By various mechanisms the organic and inorganic matter gets attached to the grains of sand. It removes the pathogenic microbes, colour and odour Here the crusher sand of 600 micron size is used as the filtering media. Crusher sand is an alternative to Natural River sand it suitably fits the place of river sand. Due to the scarcity of river sand it is economical to use crusher sand. It is the crushed rock sand which is the eminent source now a day's used in various purposes. The depth of sand about $30 \mathrm{~cm}$ is taken for this experiment. Before the experimental setup the sand is completely washed to remove the dust particles and the colour.

\section{Natural Zeolites}

Natural zeolite is the hydrated aluminosilicates complex. It is found only in fissures of volcanic rock. It is has good potential in removing the hardness of waste water. It mainly contains $\mathrm{SiO}_{4}, \mathrm{AlO}_{4}$ and oxygen. It is a three dimensional crystalline structure which is connected by oxygen. It has good adsorption and ion exchange properties. Due to its less pore size than sand it involves in effective removal

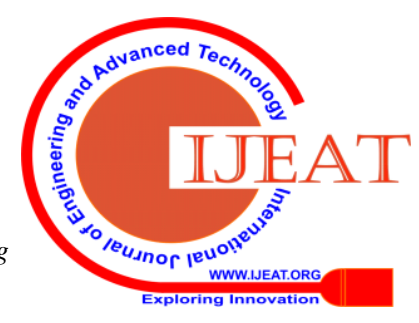




\section{Treatment of Grey Water Using Natural Zeolites}

of metal ions. It is also referred to as molecular sieve. Cation and anion is the important property of zeolite in the waste water treatment. The efficiency of treatment using natural zeolite depends on initial concentration of metal ions, the $\mathrm{pH}$ and the amount of water should be purified. The natural zeolite powder employed here by varying the depth to increase the efficiency of removal of metal ions.

\section{EXPERIMENTAL SETUP\& PROCEDURE}

In this project the setup for the experiment is adopted in an economical way. The easily available materials are used for the setup. The setup is made in a small prototype model. A packed drinking can is used in the model setup. The can after the usage is taken and cut at the top and small holes are put at the bottom. The layer of sand is filled up to the depth of $30 \mathrm{~cm}$ and it is slightly compacted. And to that a layer of zeolite is filled. The depth is varied for the series of time and the water is collected. For the first 1 hour the zeolite depth is about $1 \mathrm{~cm}$ and second 1 hour the zeolite depth is about $2 \mathrm{~cm}$ and for the third 1 hour the zeolite depth is about $3 \mathrm{~cm}$ and so on. The arrangement is made for collecting the treated water at the bottom of the can. Batch process is adopted for this experiment.

- To treat the grey water collected, the prototype model is made using available materials. Batch process is adopted because of the small quantity of treatment.

- In the first instance the sand is filled up to a depth of 30 $\mathrm{cm}$, and spread out uniformly.

- And the layer of zeolite is filled up for $1 \mathrm{~cm}$ depth for the first one hour.

- The grey water is poured from the top, the water thus poured passed through the layer of zeolite and sand and it is collected at the bottom.

- The sample is allowed to stand for 12 hours.

- As a result, the zeolite powder reacts with the grey water, by adsorption and exchanging the metal ions present in it and by removing the hardness.

- After 24 hours, the treated water is collected at the bottom. The water is then tested for hardness using volumetric analysis. And the reading is noted.

- The above procedure was done by varying the depth of zeolite bed like $1 \mathrm{~cm}, 2 \mathrm{~cm}$ up to $5 \mathrm{~cm}$ at different time intervals.

- Then the treated water is collected and undergone hardness test. And the reading is noted.

- The step is then repeated for three consecutive depth 3 $\mathrm{cm}, 4 \mathrm{~cm}, 5 \mathrm{~cm}$. And the reading is noted.

- And the collected water undergoes hardness test and the reading is noted.

- Finally the values are compared to the hardness level of raw water. And the efficiency is calculated.

\section{A. Characteristics of Grey water}

The grey water characteristics referred to as various parameters such as $\mathrm{pH}$, turbidity, hardness, chlorides, sulphates, alkalinity and ammonia nitrogen, BOD, COD and TSS etc. These characteristics vary from place to place according to the usage depending upon the standards of living and food habits. For this research the grey water from the institution is taken. The parameters are analyzed in the lab scale, and the values are given below.

TABLE I

CHARACTERISTICS OF GREY WATER BEFORE AND AFTER TREATMENT

\begin{tabular}{|c|c|c|c|}
\hline \multirow{2}{*}{$\begin{array}{l}\text { Paramete } \\
\text { rs }\end{array}$} & \multirow{2}{*}{$\begin{array}{l}\text { Before } \\
\text { Treatment }\end{array}$} & \multicolumn{2}{|c|}{$\begin{array}{c}\text { Drinking water standards (IS } \\
\text { 10500:2012) }\end{array}$} \\
\hline & & $\begin{array}{l}\text { Desirable } \\
\text { limit }\end{array}$ & $\begin{array}{l}\text { Permissible } \\
\text { limit }\end{array}$ \\
\hline $\mathrm{pH}$ & 7.11 & $6.5-8.5$ & No relaxation \\
\hline Hardness & $1160 \mathrm{mg} / \mathrm{l}$ & 300 & 600 \\
\hline $\begin{array}{l}\text { Chloride } \\
\text { S }\end{array}$ & $507.65 \mathrm{mg} / \mathrm{l}$ & 250 & 1000 \\
\hline Sulphate & $907.2 \mathrm{mg} / \mathrm{l}$ & 200 & 400 \\
\hline $\begin{array}{l}\text { Alkalinit } \\
\mathrm{y}\end{array}$ & $495 \mathrm{mg} / \mathrm{l}$ & 200 & 600 \\
\hline Solids & $1000 \mathrm{mg} / \mathrm{l}$ & 500 & 2000 \\
\hline $\begin{array}{l}\text { Ammoni } \\
\text { a } \\
\text { nitrogen }\end{array}$ & $25 \mathrm{mg} / \mathrm{l}$ & 50 & - \\
\hline $\begin{array}{l}\text { Turbidit } \\
\mathrm{y}\end{array}$ & $127.5 \mathrm{NTU}$ & 5 & 10 \\
\hline BOD & $220 \mathrm{mg} / \mathrm{l}$ & 350 & - \\
\hline
\end{tabular}

\section{RESULTS AND DISCUSSIONS}

The treated water (Fig 4 to 8 ) is collected and hardness is tested and compared with the raw water results.

TABLE II

ChARACTERISTICS AT THE END OF 12HOURS

\begin{tabular}{|c|c|c|c|c|c|c|}
\hline \multirow[b]{2}{*}{$\begin{array}{c}\text { Paramete } \\
\text { rs }\end{array}$} & \multirow[b]{2}{*}{$\begin{array}{l}\text { Raw } \\
\text { water }\end{array}$} & \multicolumn{5}{|c|}{ Treated grey water } \\
\hline & & $\begin{array}{l}\text { For } \\
1 \mathrm{~cm} \\
\text { dept } \\
\mathrm{h}\end{array}$ & $\begin{array}{l}\text { For } \\
2 \mathrm{~cm} \\
\text { dept } \\
\mathrm{h}\end{array}$ & $\begin{array}{l}\text { For } \\
3 \mathrm{~cm} \\
\text { dept } \\
\mathrm{h}\end{array}$ & $\begin{array}{l}\text { For } 4 \\
\mathrm{~cm} \\
\text { depth }\end{array}$ & $\begin{array}{l}\text { For } 5 \\
\mathrm{~cm} \\
\text { depth }\end{array}$ \\
\hline $\begin{array}{l}\text { Total } \\
\text { hardness }\end{array}$ & $\begin{array}{l}1160 \\
\mathrm{mg} / \mathrm{l}\end{array}$ & $\begin{array}{l}990 \\
\mathrm{mg} / \mathrm{l}\end{array}$ & $\begin{array}{l}900 \\
\mathrm{mg} / \mathrm{l}\end{array}$ & $\begin{array}{l}820 \\
\mathrm{mg} / \mathrm{l}\end{array}$ & $\begin{array}{l}730 \\
\mathrm{mg} / \mathrm{l}\end{array}$ & $\begin{array}{l}675 \\
\mathrm{mg} / \mathrm{l}\end{array}$ \\
\hline $\begin{array}{l}\text { Permane } \\
\text { nt } \\
\text { hardness }\end{array}$ & $\begin{array}{l}640 \\
\mathrm{mg} / \mathrm{l}\end{array}$ & $\begin{array}{l}520 \\
\mathrm{mg} / \mathrm{l}\end{array}$ & $\begin{array}{l}460 \\
\mathrm{mg} / \mathrm{l}\end{array}$ & $\begin{array}{l}420 \\
\mathrm{mg} / 1\end{array}$ & $\begin{array}{l}380 \\
\mathrm{mg} / \mathrm{l}\end{array}$ & $\begin{array}{l}350 \\
\mathrm{mg} / \mathrm{l}\end{array}$ \\
\hline $\begin{array}{l}\text { Tempora } \\
\text { ry } \\
\text { hardness }\end{array}$ & $\begin{array}{l}520 \\
\mathrm{mg} / \mathrm{l}\end{array}$ & $\begin{array}{l}470 \\
\mathrm{mg} / \mathrm{l}\end{array}$ & $\begin{array}{l}440 \\
\mathrm{mg} / \mathrm{l}\end{array}$ & $\begin{array}{l}400 \\
\mathrm{mg} / 1\end{array}$ & $\begin{array}{l}350 \\
\mathrm{mg} / \mathrm{l}\end{array}$ & $\begin{array}{l}325 \\
\mathrm{mg} / 1\end{array}$ \\
\hline
\end{tabular}

TABLE III

CHARACTERISTICS AT THE END OF 14HOURS

Treated grey water

\begin{tabular}{|c|c|c|c|c|c|c|}
\hline $\begin{array}{c}\text { Paramete } \\
\text { rs }\end{array}$ & $\begin{array}{l}\text { Raw } \\
\text { water }\end{array}$ & $\begin{array}{l}\text { For } \\
1 \mathrm{~cm} \\
\mathrm{dept} \\
\mathrm{h}\end{array}$ & $\begin{array}{l}\text { For } \\
2 \mathrm{~cm} \\
\text { dept } \\
\mathrm{h}\end{array}$ & $\begin{array}{l}\text { For } \\
3 \mathrm{~cm} \\
\text { dept } \\
\mathrm{h}\end{array}$ & $\begin{array}{l}\text { For } 4 \\
\mathrm{~cm} \\
\text { depth }\end{array}$ & $\begin{array}{l}\text { For } 5 \\
\mathrm{~cm} \\
\text { depth }\end{array}$ \\
\hline $\begin{array}{l}\text { Total } \\
\text { hardness }\end{array}$ & $\begin{array}{l}1160 \\
\mathrm{mg} / \mathrm{l}\end{array}$ & $\begin{array}{l}962 \\
\mathrm{mg} / 1\end{array}$ & $\begin{array}{l}870 \\
\mathrm{mg} / \mathrm{l}\end{array}$ & $\begin{array}{l}770 \\
\mathrm{mg} / 1\end{array}$ & $\begin{array}{l}684 \\
\mathrm{mg} / 1\end{array}$ & $\begin{array}{l}620 \\
\mathrm{mg} / \mathrm{l}\end{array}$ \\
\hline
\end{tabular}




\begin{tabular}{lllllll}
\hline \hline $\begin{array}{l}\text { Permane } \\
\text { nt } \\
\text { hardness }\end{array}$ & $\begin{array}{l}640 \\
\mathrm{mg} / \mathrm{l}\end{array}$ & $\begin{array}{l}512 \\
\mathrm{mg} / \mathrm{l}\end{array}$ & $\begin{array}{l}440 \\
\mathrm{mg} / \mathrm{l}\end{array}$ & $\begin{array}{l}390 \\
\mathrm{mg} / \mathrm{l}\end{array}$ & $\begin{array}{l}357 \\
\mathrm{mg} / \mathrm{l}\end{array}$ & $\begin{array}{l}320 \\
\mathrm{mg} / \mathrm{l}\end{array}$ \\
\hline $\begin{array}{l}\text { Tempora } \\
\text { ry }\end{array}$ & 520 & 450 & 430 & 380 & 327 & 300 \\
hardness & $\mathrm{mg} / \mathrm{l}$ & $\mathrm{mg} / \mathrm{l}$ & $\mathrm{mg} / \mathrm{l}$ & $\mathrm{mg} / \mathrm{l}$ & $\mathrm{mg} / \mathrm{l}$ & $\mathrm{mg} / \mathrm{l}$ \\
\hline \hline
\end{tabular}

TABLE IV

CHARACTERISTICS AT THE END OF 16HOURS

\begin{tabular}{|c|c|c|c|c|c|c|}
\hline \multirow[b]{2}{*}{$\begin{array}{c}\text { Paramete } \\
\text { rs }\end{array}$} & \multirow[b]{2}{*}{$\begin{array}{c}\text { Raw } \\
\text { water }\end{array}$} & \multicolumn{5}{|c|}{ Treated grey water } \\
\hline & & $\begin{array}{l}\text { For } \\
1 \mathrm{~cm} \\
\text { dept } \\
\mathrm{h}\end{array}$ & $\begin{array}{l}\text { For } \\
2 \mathrm{~cm} \\
\text { dept } \\
\mathrm{h}\end{array}$ & $\begin{array}{l}\text { For } \\
3 \mathrm{~cm} \\
\text { dept } \\
\mathrm{h}\end{array}$ & $\begin{array}{l}\text { For } 4 \\
\mathrm{~cm} \\
\text { depth }\end{array}$ & $\begin{array}{l}\text { For } 5 \\
\mathrm{~cm} \\
\text { depth }\end{array}$ \\
\hline $\begin{array}{l}\text { Total } \\
\text { hardness }\end{array}$ & $\begin{array}{l}1160 \\
\mathrm{mg} / \mathrm{l}\end{array}$ & $\begin{array}{l}910 \\
\mathrm{mg} / \mathrm{l}\end{array}$ & $\begin{array}{l}820 \\
\mathrm{mg} / \mathrm{l}\end{array}$ & $\begin{array}{l}730 \\
\mathrm{mg} / \mathrm{l}\end{array}$ & $\begin{array}{l}630 \\
\mathrm{mg} / \mathrm{l}\end{array}$ & $\begin{array}{l}575 \\
\mathrm{mg} / \mathrm{l}\end{array}$ \\
\hline $\begin{array}{l}\text { Permane } \\
\text { nt } \\
\text { hardness }\end{array}$ & $\begin{array}{l}640 \\
\mathrm{mg} / 1\end{array}$ & $\begin{array}{l}489 \\
\mathrm{mg} / \mathrm{l}\end{array}$ & $\begin{array}{l}420 \\
\mathrm{mg} / \mathrm{l}\end{array}$ & $\begin{array}{l}400 \\
\mathrm{mg} / \mathrm{l}\end{array}$ & $\begin{array}{l}350 \\
\mathrm{mg} / \mathrm{l}\end{array}$ & $\begin{array}{l}305 \\
\mathrm{mg} / \mathrm{l}\end{array}$ \\
\hline $\begin{array}{l}\text { Tempora } \\
\text { ry } \\
\text { hardness }\end{array}$ & $\begin{array}{l}520 \\
\mathrm{mg} / 1\end{array}$ & $\begin{array}{l}421 \\
\mathrm{mg} / 1\end{array}$ & $\begin{array}{l}400 \\
\mathrm{mg} / \mathrm{l}\end{array}$ & $\begin{array}{l}330 \\
\mathrm{mg} / \mathrm{l}\end{array}$ & $\begin{array}{l}280 \\
\mathrm{mg} / \mathrm{l}\end{array}$ & $\begin{array}{l}270 \\
\mathrm{mg} / \mathrm{l}\end{array}$ \\
\hline
\end{tabular}
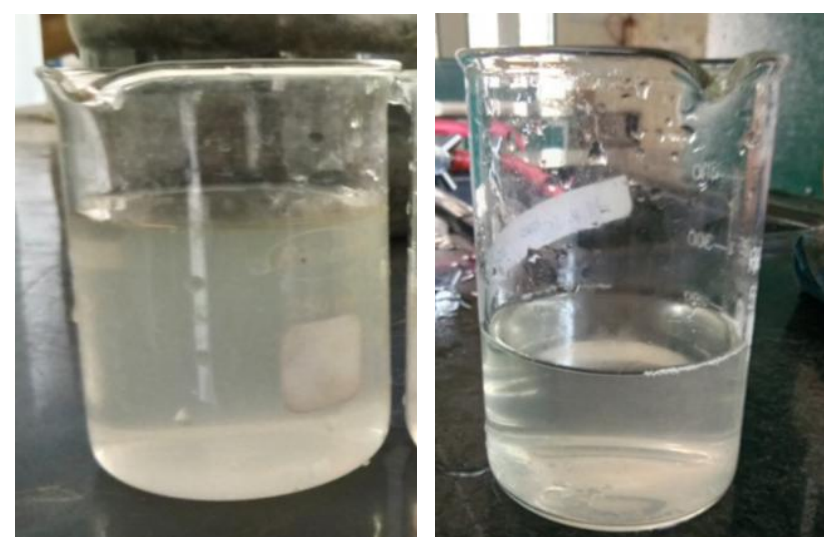

Fig. 1. Treated water at $1 \mathrm{~cm}$ depth Fig. 2. Treated water at $2 \mathrm{~cm}$ depth
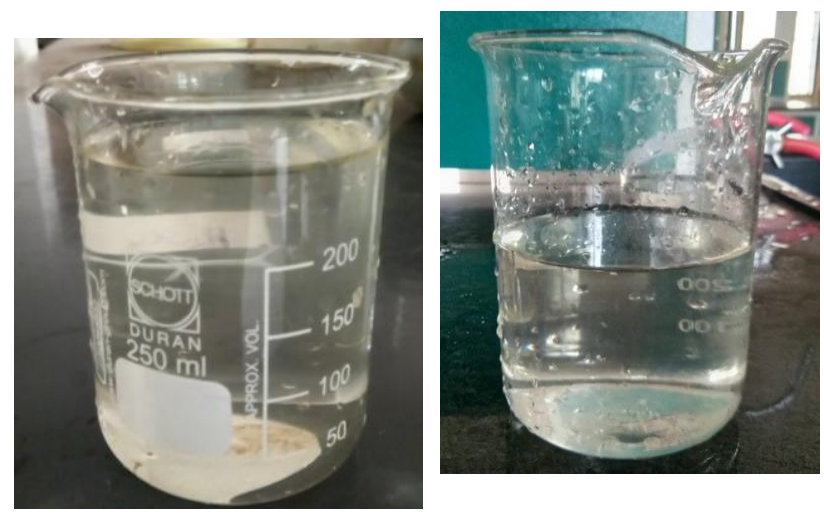

Fig. 3. Treated water at $3 \mathrm{~cm}$ depth Fig. 4. Treated water at $4 \mathrm{~cm}$ depth

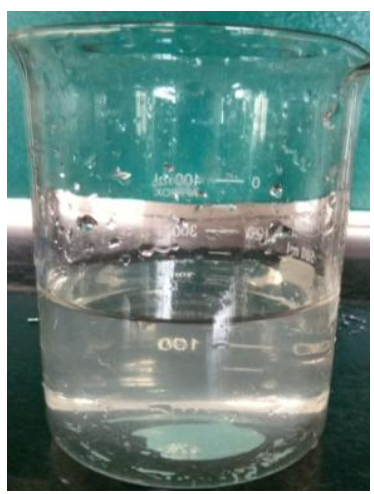

Fig. 5. Treated water at $5 \mathrm{~cm}$ depth

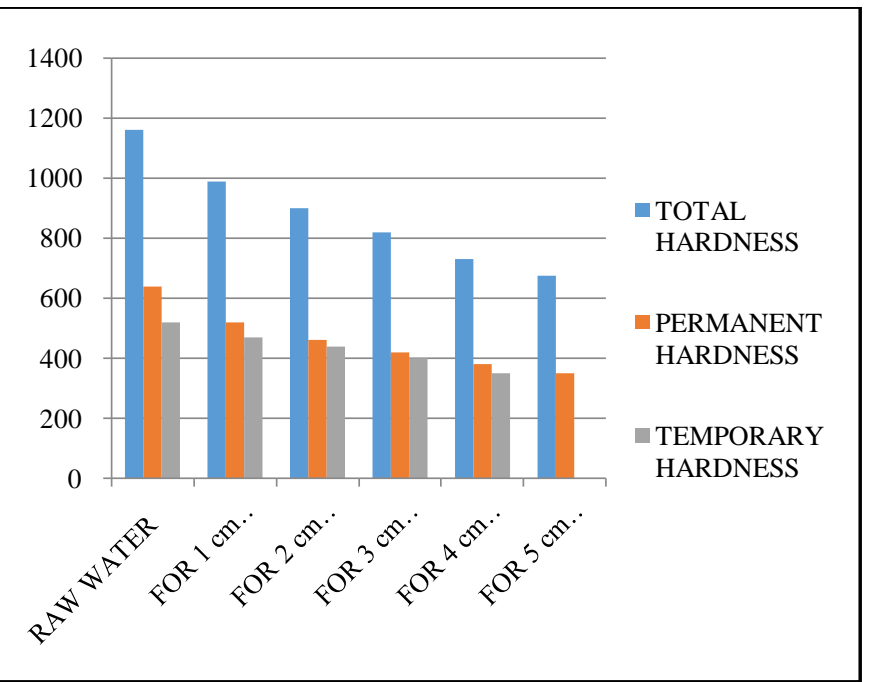

Fig. 6. Hardness at different depths of zeolites at the end of 12 hours

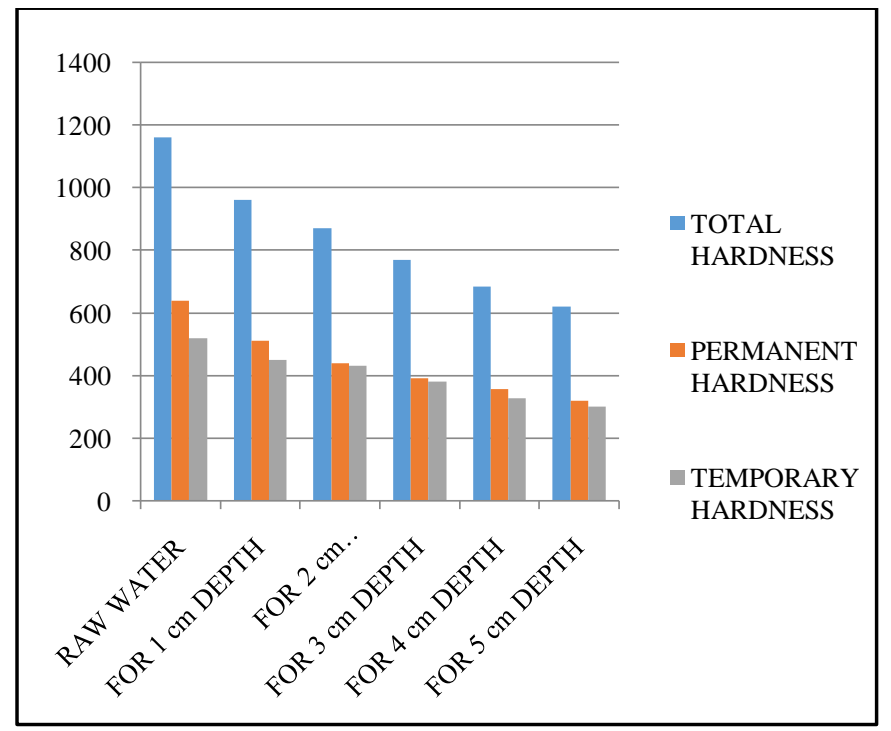

Fig. 7. Hardness at different depths of zeolites at the end of 14 hours

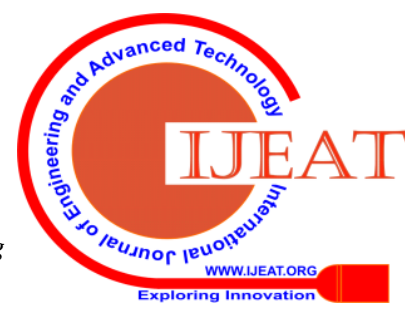




\section{Treatment of Grey Water Using Natural Zeolites}

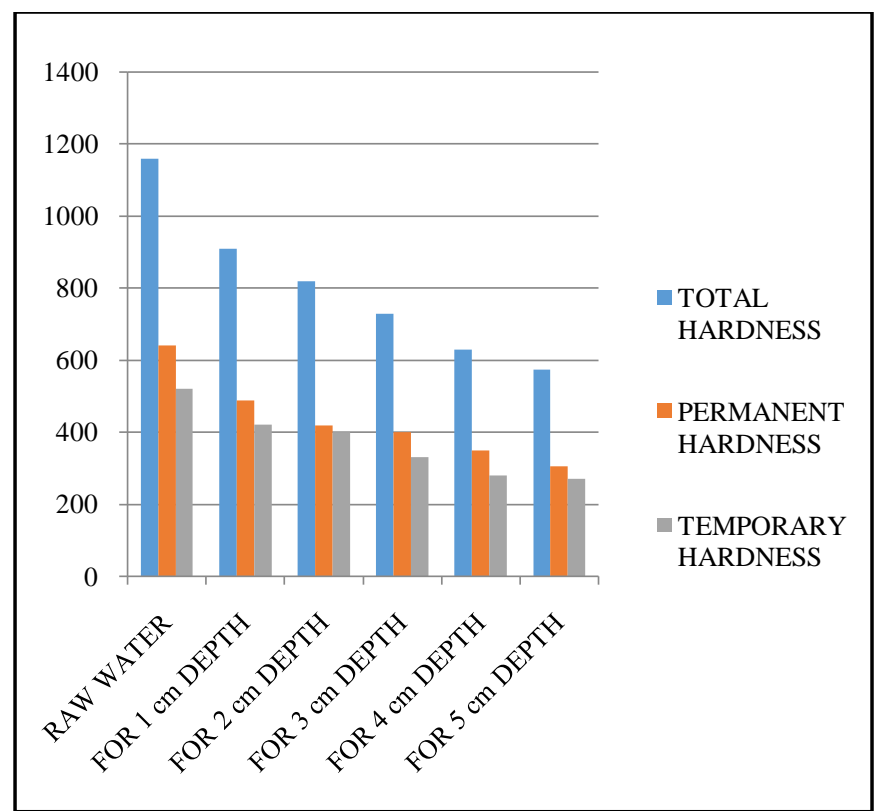

Fig. 8. Hardness at different depths of zeolites at the end of 16 hours

From the results we conclude that there is a progressive decrease in the hardness level of grey water on using natural zeolite powder. By consecutive increase in the depth of natural zeolite powder expected results are obtained. Natural zeolite powder act as a good adsorbent and it works efficiently in the removal of metal ions. Odour of the grey water is also reduced after the treatment. As it is natural available from rocks, it is easily available in market. In the same way after the treatment with zeolite powder it does not produce any harmful waste by product. So there will be no necessary for waste after treatment.

\section{CONCLUSION}

Natural zeolite is the new technology in the treatment of grey water. Because of its high purification and easy availability, it is very advantageous for treating the grey water. The main work of these natural zeolites is to remove the metal ion present in the grey water. Due to this the hardness is removed, hardness in the sense removal of heavy metal ions. And it produces less cautious waste after the treatment. Many researchers have found that it is more effective in the removal of heavy metals. In this laboratory scale research, found that it is effective to remove expected amount of hardness. It also removes the odour from the treated grey water and the colour changes. Further research can be done in the large scale treatment by adopting different natural zeolites. There are 40 number of natural zeolites are available. And also by modifying the structure of the natural zeolite, the research can also be progressed.

\section{REFERENCES}

1. Nurul Widiastuti, Hongwi Wu, Ha Ming Ang. "The potential application of natural zeolite for grey water", January 2008, 218 (2008) 271-280, DOI: 10.1016/j.desal.2007.02.022.

2. Karmen Margeta, Nataša Zabukovec Logar, Mario Šiljeg and Anamarija Farkaš. "Natural Zeolites in Water Treatment - How Effective is Their Use", January 2013, http://dx.doi.org/10.5772/50738

3. Karnapa Ajit, "A Review on Grey Water Treatment and Reuse", International Research Journal of Engineering and Technology (IRJET), Volume: 03 Issue: 05 | May-2016.
4. Parameshwara Murthy P.M, Sadashiva Murthy B.M, Kavya S, "Grey water Treatment and Reuse : ATechnological Review", Global Journal for Research Analysis, Volume - 5, Issue - 3, March - 2016. 5. Barlokova D, "Natural Zeolites in the Water Treatment Process", Slovak Journal of Civil Engineering, 2008.

6. Dariusz Andraka, Lech Dzienis, Menlibai Myrzakhmetov, Kairat Ospanov, "Application of Natural Zeolite for Intensification of Municipal Wastewater Treatment", Journal of Ecological Engineering, Volume 18, Issue 2, March 2017.

7. Denes Kallo, "Applications of Natural Zeolites in Water and Wastewater Treatment", DOI: 10.1238/rmg.2001.45.15.

8. Ciambelli P, Corbo P, Porcelli c, Rimoli A, “Ammonia Removal from Wastewater by Natural Zeolites", Zeolites 5:184-187.

9. Misaelides P, "Application of natural zeolites in environmental remediation: A short review", Micropor.Mesopor.Mater. 144:15-18, 2011.

10. Fu F, Wang Q, "Removal of heavy metal ions from wastewaters: A review". Journal of Environmental Management.92:407-418, 2011 11. Wang S, Peng Y, "Natural zeolites as effective adsorbents in water and wastewater treatment", Journal of Chemical Engineering. 156:11-24, 2010.

\section{Author Profile}

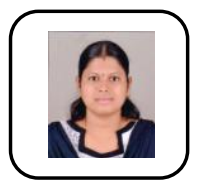

Jamuna.M working as Assistant Professor in the department of Civil Engineering at Kumaraguru College of Technology, Coimbatore. I am having a teaching experience of 4.2 years. Currently pursuing $\mathrm{PhD}$ in Environmental Engineering Discipline. Completed my Post Graduate in Environmental Engineering from Gnanamani College of Engineering, Namakkal with a CGPA of 8.7 in the year 2015 and Under Graduate in Civil Engineering from K.S.Rangasamy College of Technology, Tiruchengode with a CGPA of 9.2 in the year 2012. Won gold medal for securing top rank in under graduate programme. Participated and presented five number of papers in the national and international conferences and also Published two number of papers in international journal.

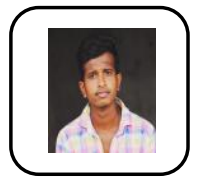

Manoj.N pursuing Masters in Environmental Engineering at Kumaraguru College of Technology, Coimbatore. Completed my Under Graduate in Civil Engineering from Kongu Engineering College, Erode with a CGPA of 8 in the year 2018. Secretary of Ravi Varma Creative Club from 2016 to 2018. Student member in Rotract club from 2015 to 2018. Published one of paper in international journal. Participated in the national and international conferences.

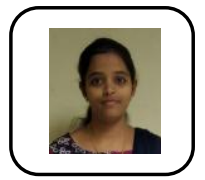

Sangeetha.A pursuing Masters in Environmental Engineering at Kumaraguru College of Technology, Coimbatore. Completed my Under Graduate in Civil Engineering from Karpagam Engineering College, Erode with a CGPA of 9.2 in the year 2018. Student member in Indian Geotechnical Society 2015 2018.Student member in Indian Concrete Institute 2017-2018. Participated in the national and international conferences. 